\title{
Corticotrophin-releasing activity of desmopressin in Cushing's disease: lack of correlation between in vivo and in vitro responsiveness
}

\author{
F Pecori Giraldi, E Marini, E Torchiana, P Mortini ${ }^{1}$, A Dubini \\ and $\mathbf{F}$ Cavagnini \\ Chair of Endocrinology, University of Milan, Ospedale San Luca, Istituto Auxologico Italiano, Istituto di Ricovero e Cura a Carattere Scientifico, \\ via Spagnoletto 3, 20149 Milan, Italy \\ ${ }^{1}$ Department of Neurosurgery, Ospedale San Raffaele, Istituto di Ricovero e Cura a Carattere Scientifico, Milan, Italy \\ (Requests for offprints should be addressed to F Pecori Giraldi; Email: fpg@auxologico.it)
}

\begin{abstract}
Desmopressin (DDAVP), an arginine vasopressin analogue, markedly stimulates ACTH secretion in patients with Cushing's disease, in contrast to its minimal effect in normal subjects. However, little is known about the mechanisms underlying this action and it appeared to be of interest to evaluate the effect of DDAVP on ACTHsecreting pituitary adenomas in vitro, in comparison with its effect in the same patients in vivo. Pituitary adenomas from 14 patients with Cushing's disease were incubated with DDAVP, corticotrophin-releasing hormone (CRH) and DDAVP together with vasopressin receptor antagonists or CRH. Incubation with DDAVP induced a modest dose-dependent increase in ACTH concentrations which appeared maximal at $10 \mathrm{nM}$. CRH stimulated ACTH to a greater extent compared with DDAVP and potentiated the effect of DDAVP alone. The DDAVP-induced
\end{abstract}

ACTH increase appeared blunted by vasopressin $V_{2}$ and $\mathrm{V}_{3}$ receptor antagonists. $\mathrm{V}_{3}$ receptor gene expression was detected by RT-PCR in all adenoma samples except for two which were not responsive to DDAVP in vitro but responsive to the peptide in vivo. Surprisingly, no difference in the in vitro ACTH secretory response was observed between in vivo DDAVP-responsive (ACTH peak>150\% baseline) and -unresponsive (ACTH peak $<120 \%$ baseline) patients, suggesting that the pituitary adenoma is not the sole mediator of the ACTH-releasing effect of DDAVP. In conclusion, the marked stimulatory effect of DDAVP observed in patients with Cushing's disease appears to be mainly dependent on an extrapituitary action, possibly the inhibition of a corticotrophin release-inhibitory factor. Journal of Endocrinology (2003) 177, 373-379

\section{Introduction}

Desmopressin (DDAVP), the long-acting analogue of arginine vasopressin (AVP), has recently been shown to markedly stimulate corticotrophin (ACTH) and cortisol secretion in patients with Cushing's disease (Malerbi et al. 1993, Colombo et al. 1997, Sakai et al. 1997, Moro et al. 2000). This behaviour is typical for patients with an ACTH-secreting pituitary tumour as DDAVP exerts only a modest stimulatory effect in normal subjects (Andersson et al. 1972, Gaillard et al. 1988) and in patients with pseudoCushing syndrome (i.e. patients with alcoholism, obesity and depression, presenting clinical and/or biochemical features resembling Cushing's disease) (Malerbi et al. 1996, Tsagarakis et al. 1999, Coiro et al. 2000, Moro et al. 2000). On the basis of this evidence, we recently recommended the use of DDAVP in the differential diagnosis between mild forms of Cushing's disease and pseudoCushing syndrome (Moro et al. 2000).
The mechanisms whereby DDAVP selectively stimulates ACTH secretion in patients with Cushing's disease are not yet fully understood. DDAVP is a known agonist for the $\mathrm{V}_{2}$ receptor (i.e. kidney receptor) but has also been shown to bind the $\mathrm{V}_{3}$ receptor isoform (Thibonnier et al. 1998). This latter is a characteristic of ACTH-secreting cells, both within and without the pituitary (Lolait et al. 1995, De Keyzer et al. 1996), and is apparently overexpressed in tumoural corticotrophs (Dahia et al. 1996, De Keyzer et al. 1998), thus possibly subserving the marked response to DDAVP observed in patients with Cushing's disease.

The aim of the present study was to evaluate the response to DDAVP in pituitary ACTH-secreting adenomas in vitro, in comparison with the response observed in vivo in the same patients prior to surgery. In addition, we investigated the AVP receptor subtype involved in this response by performing co-incubation experiments with DDAVP and AVP receptor antagonists and by evaluating 
$\mathrm{V}_{3}$ receptor mRNA in individual tumour cultures. Lastly, the effect of DDAVP on ACTH was compared with the selfsame response to corticotrophin-releasing hormone $(\mathrm{CRH})$, alone and together with DDAVP itself.

\section{Materials and Methods}

\section{Patients}

Fourteen patients with an ACTH-secreting pituitary adenoma (eleven females and three males; age 40.0 $\pm 3 \cdot 39$ years, range 20-68) were studied. Diagnosis of Cushing's disease was established by standard criteria (Invitti et al. 1999a), including stimulation with CRH in six patients, and confirmed by results of pituitary pathology. Tumour size was greater than $1 \mathrm{~cm}$ in patients 1, 2, 4, 9-11 and 13, the remainder presenting a microadenoma (size range 6-9 $\mathrm{mm})$.

\section{In vivo studies}

Preoperative testing with DDAVP was performed as previously described (Moro et al. 2000). In short, DDAVP $(10 \mu \mathrm{g}$; Minirin, Ferring Pharmaceuticals Ltd, Malmo, Sweden) was injected in the morning after an overnight fast and serum samples were collected prior to and 15, 30, 45, 60, 90 and 120 min after the injection. Plasma ACTH levels were measured by immunoradiometric assay (Nichols Institute, San Juan Capistrano, CA, USA). In our laboratory, intra- and interassay coefficients of variation are $3 \cdot 2$ and $8 \cdot 2 \%$ respectively. In order to clearly differentiate DDAVP-responsive and -unresponsive patients we adopted stringent response criteria: a peak increase in ACTH levels greater than $150 \%$ of baseline identified responders whereas an ACTH peak less than $120 \%$ of baseline identified non-responders. These separate cut-offs were purposely chosen to allow a clear characterization of the in vivo DDAVP response pattern.

\section{In vitro studies}

ACTH-secreting pituitary adenomas were collected during trans-sphenoidal surgery and established in culture according to our usual protocol (Invitti et al. 1999b). Briefly, adenomas were enzymatically dispersed, checked for viability, plated at a density of $2 \times 10^{5}$ cells/well, and incubated in Dulbecco's modified Eagle's medium (DMEM), 10\% fetal calf serum and antibiotics for 3-5 days. The following treatments were performed according to the abundance of the tumour specimen: (1) $1 \mathrm{nM}-$ $10 \mu \mathrm{M}$ DDAVP, (2) $10 \mathrm{nM}$ CRH, (3) $10 \mathrm{nM} \mathrm{CRH}$ and $10 \mathrm{nM}-1 \mu \mathrm{M}$ DDAVP together, (4) $10 \mu \mathrm{M} \quad \mathrm{V}_{1}$ receptor antagonist ((3-(4-azidophenyl)propionyl ${ }^{1}, \mathrm{D}-$ Tyr(Me $)^{2}$, Arg $^{6}$, Arg $\left.^{8}, \mathrm{Tyr}_{\mathrm{NH}}{ }_{2}{ }^{9}\right)$-vasopressin) and $100 \mathrm{nM}$ DDAVP, (5) $10 \mu \mathrm{M} \mathrm{V} \mathrm{V}_{2}$ receptor antagonist $\left(\left(\mathrm{d}\left(\mathrm{CH}_{2}\right)_{5}{ }^{1}\right.\right.$, $\left.\mathrm{D}-\mathrm{Ile}^{2}, \mathrm{Ile}^{4}, \mathrm{Arg}^{8}, \mathrm{Ala}^{-\mathrm{NH}_{2}}{ }^{9}\right)$-vasopressin) and $100 \mathrm{nM}$ DDAVP, (6) $10 \mu \mathrm{M} \mathrm{V}_{3}$ receptor antagonist (des-Gly ${ }^{9}-(\beta-$ mercapto- $\beta, \beta$-cyclopentamethylenepropionyl ${ }^{1}, \mathrm{O}-\mathrm{Et}-\mathrm{Tyr}^{2}$, $\mathrm{Val}^{4}, \mathrm{Arg}^{8}$ )-vasopressin) and $100 \mathrm{nM}$ DDAVP and (7) each antagonist alone. The concentration of DDAVP for coincubation experiments was purposely high in order to obtain the greatest possible ACTH increase. Control wells were incubated with DMEM and $0 \cdot 1 \%$ bovine serum albumin. Each treatment was performed in triplicate or quadruplicate. Test agents were purchased from Bachem Feinchemikalien AG, Bubendorf, Switzerland except for the $V_{3}$ receptor antagonist (Sigma Chemical Co., St Louis, MO, USA).

ACTH was measured by radioimmunoassay (Pecori Giraldi \& Cavagnini 1998) after 1- and 4-h incubations with test agents. Sensitivity, intra- and interassay coefficients of variation of this assay are $0.5 \mathrm{pg} / \mathrm{ml}, 5.9 \%$ and $6 \cdot 8 \%$ respectively.

Total RNA was extracted from pituitary adenoma primary cultures using RNAzol B (Tel Test Inc., Friendswood, TX, USA). RNA was reverse transcribed in the presence of $0.5 \mathrm{mM}$ deoxynucleoside triphosphate, $10 \mu \mathrm{M}$ random primers, $25 \mathrm{U}$ RNase inhibitor and $200 \mathrm{U}$ murine leukaemia virus reverse transcriptase for $45 \mathrm{~min}$ at $37^{\circ} \mathrm{C}$. The resulting cDNA was amplified with $500 \mathrm{nM}$ intron-spanning primers specific to the human $\mathrm{V}_{3}$ receptor gene (upstream: bp 2420-2440, downstream bp 81858205; Genebank Accession \#AF152238) and Taq DNA polymerase according to the following protocol: initial denaturing at $95^{\circ} \mathrm{C}$ for $2 \mathrm{~min}$, then $95^{\circ} \mathrm{C}$ for $20 \mathrm{~s}, 60{ }^{\circ} \mathrm{C}$ for $20 \mathrm{~s}$ and $72{ }^{\circ} \mathrm{C}$ for $30 \mathrm{~s}$ for 35 cycles, followed by a 5 -min extension at $72{ }^{\circ} \mathrm{C}$. The identity of the $\mathrm{V}_{3}$ receptor PCR product was confirmed by Southern blotting with a digoxigenin-labelled oligonucleotide (bp 7871-7892 of the human $\mathrm{V}_{3}$ receptor gene) according to the manufacturer's instructions (DIG oligonucleotide tailing kit; Boehringer Mannheim GmbH, Mannheim, Germany). RNA from a growth hormone-secreting adenoma was used as a negative control. The integrity of RNA was assessed by amplification of the hypoxanthine phosphoribosyltransferase (HPRT) gene with $250 \mathrm{nM}$ intronspanning primers (upstream: bp 570-589, downstream: bp 647-667; Genebank Accession \#NM000194) according to the same PCR protocol except for annealing at $53{ }^{\circ} \mathrm{C}$. Reagents for reverse transcription, PCR and restriction enzyme digestion were provided by Promega Corp., Madison, WI, USA.

For statistical analysis, experiments were normalized as a percentage of control and treatments were compared using Wilcoxon's statistic for non-parametric data. Qualitative data were analysed by the chi square statistic. Data are expressed as means \pm S.E.M. Statistical significance was accepted at $P<0 \cdot 05$. 

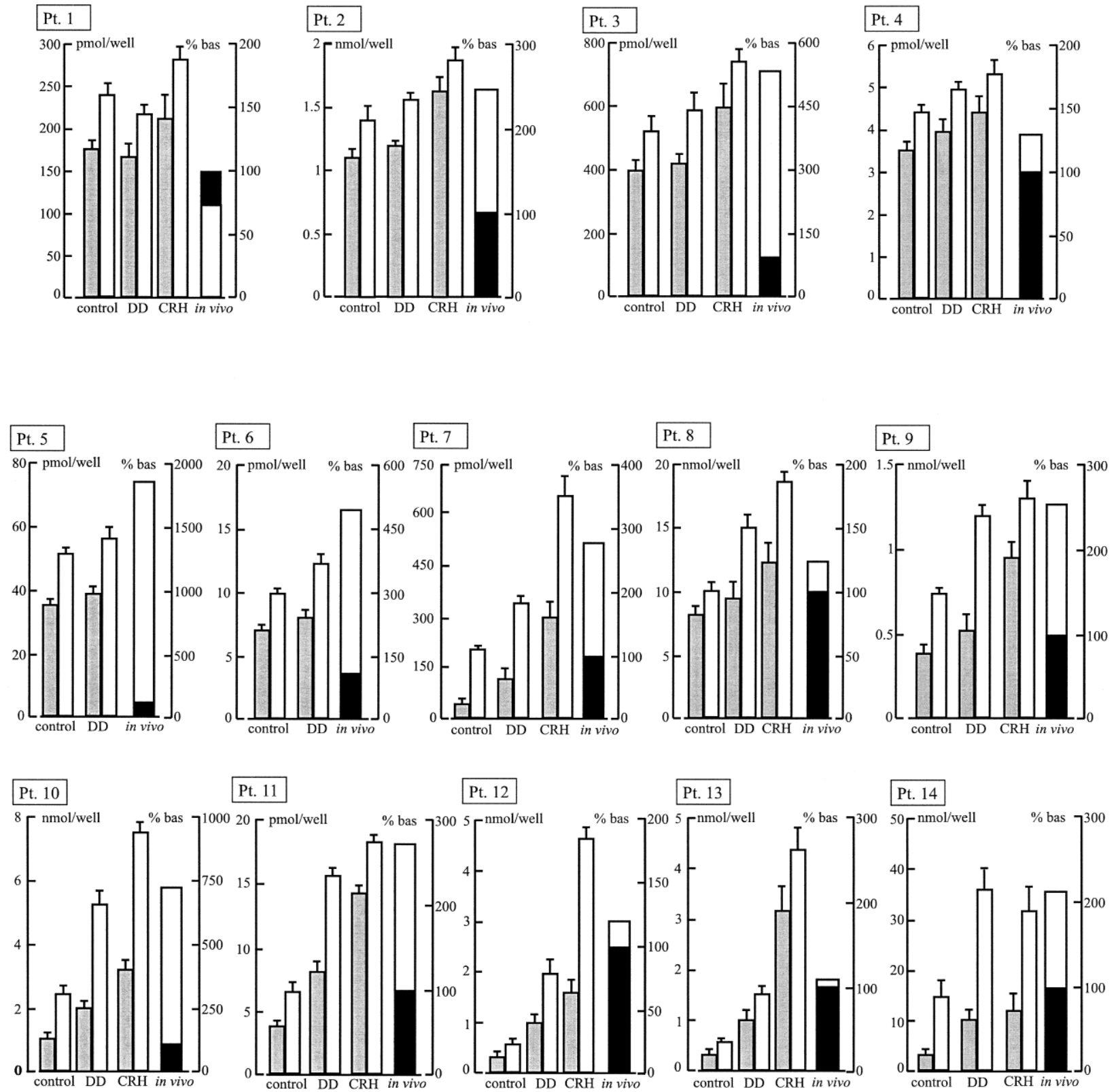

Figure 1 Effect of DDAVP on ACTH secretion by individual ACTH-secreting pituitary tumours in vivo and in vitro. The left-hand axis of each figure represents ACTH medium concentrations in tumour cultures: control wells (=control), maximal increase induced by DDAVP $(=\mathrm{DD})$ and $10 \mathrm{nM} \mathrm{CRH}(=\mathrm{CRH})$. The shaded bars represent ACTH concentrations after $1 \mathrm{~h}$ of incubation and the open bars after $4 \mathrm{~h}$ of incubation. The right-hand most bars ( =in vivo) and the right-hand axes indicate the effect of $10 \mu \mathrm{g}$ DDAVP in the same patient prior to surgery: the solid area (baseline secretion set at 100\%; \% bas) superimposed on the open area indicating ACTH \% peak. Note that DDAVP administration was followed by a decrease in ACTH in patient 1 in vivo (right-hand most bar).

\section{Results}

Testing with DDAVP in vivo identified nine patients $(2,3$, 5-7, 9-11 and 14) in whom DDAVP induced a clear ACTH increase (peak $>150 \%$ baseline) and five nonresponsive patients $(1,4,8,12$ and 13$)$, as may occur in some patients with Cushing's disease (Moro et al. 2000). There was no difference between these two groups as regards age, size of the adenoma at pituitary imaging, and basal ACTH levels.

Figure 1 shows maximal DDAVP-stimulated ACTH concentrations in individual pituitary adenoma cultures 

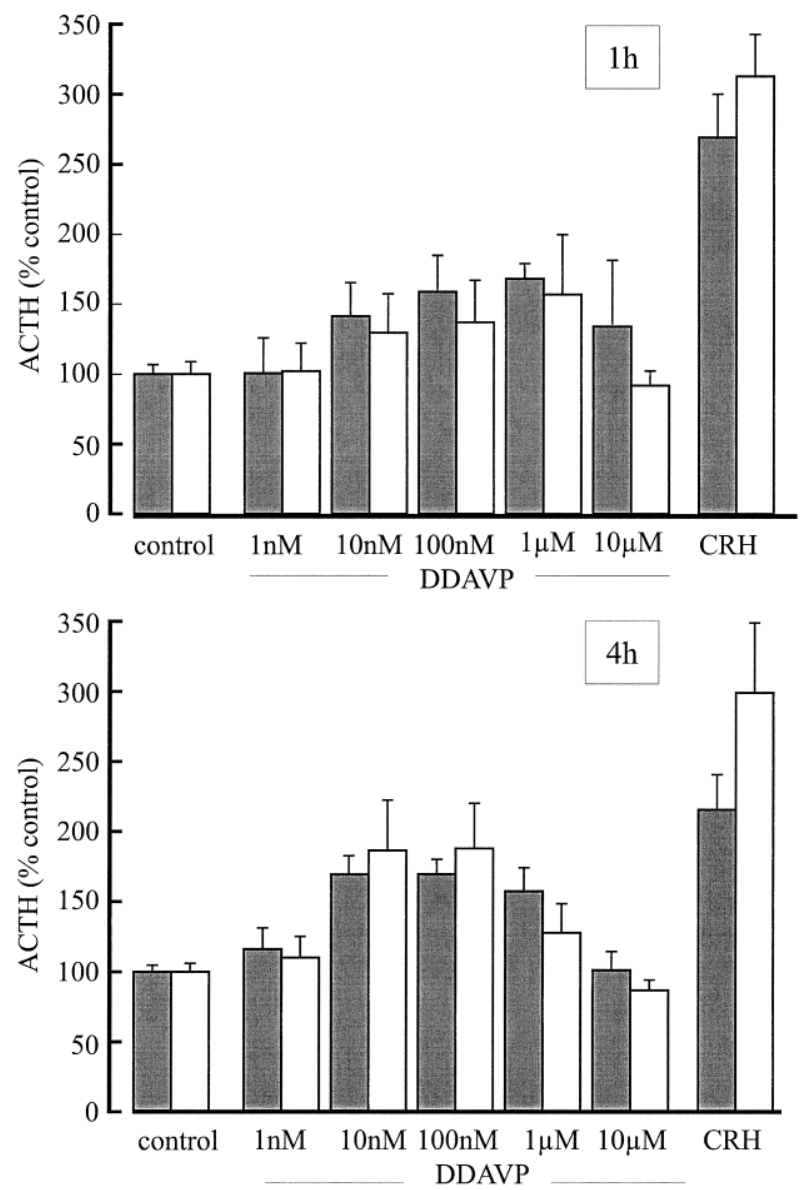

Figure 2 Mean percent variation of ACTH concentrations in tumour cultures from in vivo DDAVP-responsive (shaded bars) and -unresponsive (open bars) patients. Control secretion is set at 100\%; CRH was incubated at $10 \mathrm{nM}$.

ordered according to the strength of the in vitro ACTH response with patient 1 presenting the lowest and patient 14 the greatest response. As can be seen, the stimulatory effect of DDAVP, if present, was already apparent after $1 \mathrm{~h}$ of incubation; by $4 \mathrm{~h}$ of incubation this increase in ACTH concentration was further magnified. The stimulatory effect of DDAVP appeared to be dose-dependent (maximal stimulation at $10 \mathrm{nM}$; Fig. 2) and slightly, although not significantly, greater in micro- than in macroadenomas (maximal ACTH increase at $1 \mathrm{~h}$ : $190 \cdot 9 \pm 34 \cdot 37$ vs $164 \cdot 8 \pm 25 \cdot 58 \%$ of control, not significant (NS) and at $4 \mathrm{~h}: 174 \cdot 2 \pm 21 \cdot 10$ vs $150 \cdot 8 \pm 20 \cdot 18 \%$ of control, NS respectively). Surprisingly, no response could be observed in cultures from patients 2, 3, 5 and 6 in whom DDAVP had elicited a marked increase in ACTH levels in vivo (Fig. 1). Further, there appeared to be no correlation between the in vivo and in vitro DDAVP responsiveness as a clear-cut increase in ACTH concentrations (i.e. peak at least 50\% higher than control secre-

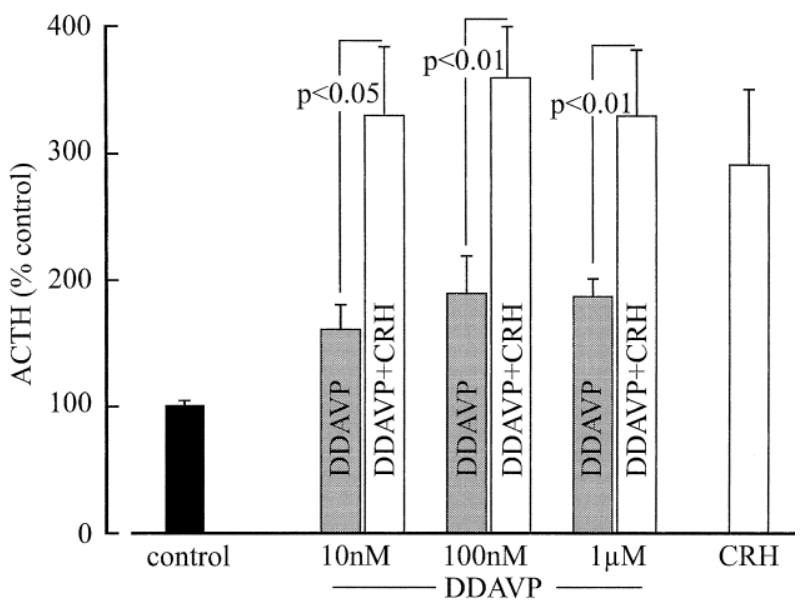

Figure 3 Mean percent variation of ACTH concentrations in tumour cultures incubated with $10 \mathrm{nM} C R H$ and $10 \mathrm{nM}-1 \mu \mathrm{M}$ DDAVP. Open bars indicate treatment with CRH with or without DDAVP and the shaded bars treatment with DDAVP alone. Control secretion is set at $100 \%$.

tion) was observed in five out of nine DDAVP responders (patients 7, 9-11 and 14) and three out of five DDAVP non-responders (patients 8, 12 and 13). Overall, no difference could be detected in the mean DDAVPinduced ACTH increase between in vivo DDAVP responders and non-responders (Fig. 2).

All tumours incubated with CRH released substantial amounts of ACTH and a comparison of DDAVP and $\mathrm{CRH}$ responses in individual tumour cultures showed that ACTH concentrations after DDAVP were mostly smaller than those after $\mathrm{CRH}$, except for patient 14 (Fig. 1); this difference was already apparent $1 \mathrm{~h}$ after incubation with the test agent. Overall, the mean DDAVP-induced increase was clearly smaller than the mean CRH-evoked response (Fig. 2) whereas, in the same patients, the peak ACTH response to the two stimuli was comparable in vivo $(483 \cdot 9 \pm 179 \cdot 15 \%$ vs $344 \cdot 8 \pm 135 \cdot 82 \%$ of baseline, NS for DDAVP and CRH respectively). The effect of CRH incubation in vitro could be compared with the ACTH response to $\mathrm{CRH}$ prior to surgery in patients $1,3,7,10$, 12 and 14. All these patients were responsive to $\mathrm{CRH}$ in vivo (peak ACTH ranging from $161 \%$ to $1267 \%$ of baseline) and their tumours gave rise to a secretory response to $\mathrm{CRH}$ in vitro (Fig. 1).

Incubation of DDAVP and CRH together was performed in five pituitary adenomas (patients 4 and 9-12). In all experiments, co-incubation with $\mathrm{CRH}$ increased the DDAVP-induced ACTH response, even in the one patient who was unresponsive to DDAVP alone (patient 4). ACTH concentrations during incubation with DDAVP+CRH were significantly higher than with DDAVP alone but not different from those with $\mathrm{CRH}$ alone (Fig. 3), thus showing that $\mathrm{CRH}$ strongly increases the ACTH response to DDAVP but the latter only slightly enhances the ACTH response to $\mathrm{CRH}$. 


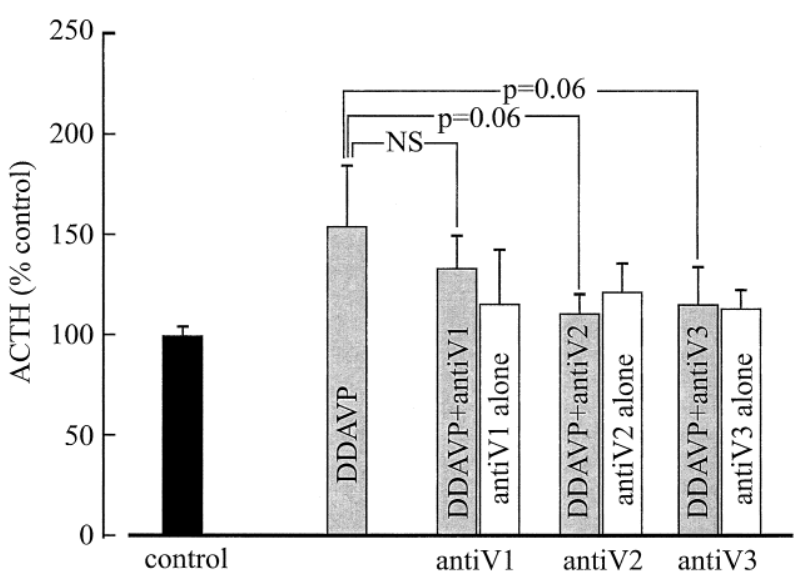

Figure 4 Mean percent variation of ACTH concentrations in tumour cultures incubated with $100 \mathrm{nM}$ DDAVP and AVP receptor antagonists. The shaded bars indicate co-incubation of DDAVP with and without receptor antagonists and the open bars incubation with antagonists alone. Control secretion is set at $100 \%$.

Incubation with AVP receptor antagonists was performed in seven tumour cultures (patients 1-3, 6-8 and 14) and did not affect ACTH concentrations (all NS). Co-incubation of DDAVP and $\mathrm{V}_{2}$ or $\mathrm{V}_{3}$ receptor antagonists in three tumours responsive to DDAVP in vitro (patients 7, 8 and 14) blunted the ACTH increase, although this effect did not reach statistical significance $\left(P=0.062\right.$ for $\mathrm{V}_{2}$ and $P=0.057$ for $\mathrm{V}_{3}$; Fig. 4). No clear-cut change in ACTH medium concentrations was observed during co-incubation with the $\mathrm{V}_{1}$ receptor antagonist (NS; Fig. 4).

$\mathrm{V}_{3}$ receptor gene expression was detected in most patients, regardless of their in vivo response status (data not shown); tumour mRNA tested positive for $\mathrm{V}_{3}$ receptor in all cultures in which DDAVP stimulated ACTH in vitro (patients 7-14) and also in some specimens unresponsive to DDAVP in vitro (patients 1-4). The integrity of mRNA in tumour cultures which failed to express the $V_{3}$ gene was established by positive amplification of the HPRT gene. The small amount of RNA obtained from each sample did not allow us to seek evidence for $V_{2}$ receptor gene expression.

\section{Discussion}

Recent years have seen a renewed interest in the action of DDAVP, a $V_{2}$ receptor agonist, on ACTH secretion. In fact, evidence collected by us and others has demonstrated that most patients with Cushing's disease present a marked increase in plasma ACTH levels following i.v. administration of DDAVP (Malerbi et al. 1993, Colombo et al. 1997, Sakai et al. 1997, Moro et al. 2000), in contrast with the barely detectable response observed in normal subjects
(Andersson et al. 1972, Gaillard et al. 1988) and patients with pseudoCushing syndrome (Malerbi et al. 1996, Tsagarakis et al. 1999, Coiro et al. 2000, Moro et al. 2000). On the basis of mRNA quantification studies, it had been hypothesized that the hyper-response observed in patients with Cushing's disease was due to an overexpression of the pituitary AVP receptor subtype (i.e. $V_{3}$ ) by the ACTHsecreting pituitary adenoma (Dahia et al. 1996, De Keyzer et al. 1998). This hypothesis relied on the fact that DDAVP, while presenting high affinity for the $V_{2}$ receptor subtype $\left(K_{\mathrm{i}} 2.7 \mathrm{nM}\right)$, also interacts with the $\mathrm{V}_{3}$ receptor $\left(K_{\mathrm{i}} 22 \mathrm{nM}\right)$ (Thibonnier et al. 1998) and thus could directly stimulate adenomatous corticotrophs.

To our knowledge, only one study has been published reporting the effect of DDAVP on primary cultures from ACTH-secreting pituitary adenomas (Sakai et al. 1997). In this series of three adenomas, DDAVP induced a variable increase in ACTH concentrations, overall far less than the release evoked by $\mathrm{CRH}$. The authors concluded that DDAVP directly stimulates ACTH secretion by tumoural corticotrophs, although no comparison with the in vivo response to DDAVP was performed (Sakai et al. 1997). An additional recent case report described a stimulatory effect of $100 \mathrm{nM}$ DDAVP on long-term cultures from an ACTH-secreting macroadenoma (Abe et al. 2000).

The evidence collected in our larger series of experiments indicates that DDAVP exerts only a modest stimulatory effect (barely 1.5-fold) on ACTH-secreting pituitary adenomas in vitro. Surprisingly, the response to DDAVP in vitro was of modest magnitude even in patients exhibiting an ACTH increase over 200\% of baseline in response to DDAVP in vivo. Indeed, incubation with DDAVP did not elicit a greater ACTH increase in adenomas from patients responsive to DDAVP compared with adenomas excised from DDAVP non-responsive patients. These data suggest a dissociation of the in vitro and in vivo ACTH responsiveness to DDAVP.

By comparison, $\mathrm{CRH}$ induced a far greater increase in ACTH concentrations in all but one specimen and this disparity is noteworthy given the fact that, in vivo, $\mathrm{CRH}$ and DDAVP elicit largely comparable ACTH increases in patients with Cushing's disease, both in terms of peak and timing of the ACTH response (Sakai et al. 1997, Putignano et al. 1999). Results of co-incubation experiments indicate that CRH and DDAVP exert additive effects on ACTH release in vitro.

It is worth recalling that the ACTH increase elicited by DDAVP in patients with Cushing's disease was unique to the analogue and distinct from the ACTH-stimulatory effect of AVP, the parent peptide. In fact, the stimulatory effect of AVP in patients with an ACTH-secreting pituitary adenoma is markedly smaller than the response of the same subjects to CRH (Liu et al. 1983, Catania et al. 1984, Dickstein et al. 1996, Sakai et al. 1997). Further, in vitro data from rat pituitary primary cultures demonstrated a different ACTH responsiveness to AVP and DDAVP 
(Antoni 1984, Knepel et al. 1984, Buckingham 1987). Evidently, DDAVP and AVP do not appear to act in the same manner on both tumoural and non-tumoural corticotrophs.

Our incubation data point towards both $\mathrm{V}_{2}$ and $\mathrm{V}_{3}$ receptor subtypes subserving the effect of DDAVP on tumoural corticotrophs. Either receptor antagonist in fact blunted the DDAVP-induced ACTH release in vitro, an observation in keeping with the expression of both receptors in tumoural corticotrophs (Dahia et al. 1996). The faint response to DDAVP per se and the involvement of both receptors may have hampered the attainment of statistical significance for individual receptor antagonists alone. In our hands, $\mathrm{V}_{3}$ receptor gene expression was detected in all tumours which exhibited a response to DDAVP in vitro as well as in primary cultures which did not respond to DDAVP. $\mathrm{V}_{3}$ receptor mRNA was not detected in two specimens, both from patients in whom DDAVP failed to stimulate ACTH secretion in vitro but were clearly responsive to DDAVP in vivo.

The direct comparison of corticotroph secretory activity in vivo and in vitro may be biased by the inherent diversity of the two experimental conditions and the possible problems related to tumour explantation and culture, such as cell damage, loss of receptor and heterogeneity of the excised specimen. In our hands, the maintained responsiveness of cultured corticotrophs to $\mathrm{CRH}$, for which there was a complete concordance between in vivo and in vitro stimulation, argues against a possible receptor loss or damage to the secretory apparatus during tumour isolation. Further, CRH responsiveness indicates the presence of adenomatous corticotrophs as neighbouring, normal corticotrophs are suppressed and unresponsive to $\mathrm{CRH}$ (Avgerinos et al. 1987, Invitti et al. 1999a). In addition, corticotroph secretory capacity was by no means exhausted by DDAVP, as indicated by the fact that CRH alone or with DDAVP was capable of inducing a significantly greater ACTH release. Therefore, even using appropriate circumspection while translating in vivo findings to in vitro conditions, our findings showed a superimposable in vitro ACTH response to DDAVP in patients who presented a clearly different response pattern in vivo. Evidently, the removal of the tumoural corticotroph from its milieu interfered with DDAVP responsiveness and some factor other than the direct stimulatory action of DDAVP on adenomatous corticotrophs must contribute to in vivo responsiveness. In this context, several scenarios can be drawn.

Theoretically, DDAVP could act at the hypothalamic level in order to stimulate $\mathrm{CRH}$, as occurs for AVP (Hedge et al. 1966, Rivier \& Vale 1983, Kjær et al. 1992). This hypothesis, however, is not unchallenged as other investigators have reported findings suggesting an inhibitory circuit from AVP to CRH (Plotsky et al. 1984). Further, normal subjects fail to respond to DDAVP in vivo and thus it is unlikely that CRH mediates the marked
DDAVP-induced increase in patients with Cushing's disease.

In an alternative hypothesis, DDAVP could act through the blunting of an endogenous inhibitor of ACTH secretion. The existence of a non-corticosteroid inhibitor of ACTH secretion has long been postulated and was recently reviewed (Engler et al. 1999, Jessop 1999). Several candidate corticotrophin-release inhibitory factors (CRIF), have been studied, such as preprothyrotrophinreleasing hormone(178-199), atrial natriuretic peptide, dopamine, lipocortin and endogenous opioids, to list but a few, although conclusive evidence for one of these factors is as yet lacking. Even oxytocin, the 'sister' neurohormone to AVP, has been postulated to inhibit ACTH secretion (Legros 2001). In view of the existence of a corticotrophin-release inhibitory tone, it stands to reason that this system might be hyperactivated in Cushing's disease. DDAVP might interfere with this inhibitor and thus cause ACTH release, much as it occurs for dopamine antagonists in hyperprolactinaemia.

In conclusion, the present study has demonstrated a discrepancy between the ACTH response to DDAVP observed in vivo in patients with Cushing's disease and the effect of DDAVP on pituitary adenoma cultures from the same patients. Our findings support the view that the bulk of the ACTH response triggered by DDAVP in patients with Cushing's disease is due to an extrapituitary mechanism, possibly inhibition of the fabled CRIF.

\section{References}

Abe T, Tachikawa T, Sasaki A, Taniyama M, Okamura Y, Izumiyama H \& Matsumoto K 2000 Histopathological and physiological characteristics of cultured human ACTH-secreting cells derived from a rapidly growing pituitary adenoma. Brain Tumor Pathology 17 133-138.

Andersson KE, Arner B, Hedner P \& Mulder JL 1972 Effects of 8-lysine-vasopressin and synthetic analogues on release of ACTH. Acta Endocrinologica 69 640-648.

Antoni FA 1984 Novel ligand specificity of pituitary vasopressin receptors in the rat. Neuroendocrinology 39 186-188.

Avgerinos PC, Chrousos GP, Nieman LK, Oldfield EH, Loriaux DL \& Cutler GB Jr 1987 The corticotropin-releasing hormone test in the post-operative evaluation of patients with Cushing's syndrome. Journal of Clinical Endocrinology and Metabolism 65 906-913.

Buckingham JC 1987 Vasopressin receptors influencing the secretion of ACTH by the rat adenohypophysis. Journal of Endocrinology 113 389-396.

Catania A, Cantalamessa L, Orsatti A, Mosca G, Minonzio F, Motta P, Reschini E \& Zanussi C 1984 Plasma ACTH response to the corticotropin releasing factor in patients with Cushing's disease. Comparison with the lysine-vasopressin test. Metabolism 33 478-481.

Coiro V, Volpi R, Capretti L, Caffarri G \& Chiodera P 2000 Desmopressin and hexarelin tests in alcohol-induced pseudo-Cushing's syndrome. Journal of Internal Medicine 247 667-673.

Colombo P, Passini E, Re T, Faglia G \& Ambrosi B 1997 Effect of desmopressin on ACTH and cortisol secretion in states of ACTH excess. Clinical Endocrinology 46 661-668. 
Dahia PLM, Ahmed-Shuaib A, Jacobs RA, Chew SL, Honegger J, Fahlbusch R, Besser GM \& Grossman AB 1996 Vasopressin receptor expression and mutation analysis in corticotropin-secreting tumors. Journal of Clinical Endocrinology and Metabolism $\mathbf{8 1}$ 1768-1771.

De Keyzer Y, Lenne F, Auzan C, Jégou S, René P, Vaudry H, Kuhn JM, Luton JP, Clauser E \& Bertagna X 1996 The pituitary V3 vasopressin receptor and the corticotroph phenotype in ectopic ACTH syndrome. Journal of Clinical Investigation 97 1311-1318.

De Keyzer Y, René P, Beldjord C, Lenne F \& Bertagna X 1998 Overexpression of vasopressin (V3) and corticotrophin-releasing hormone receptor genes in corticotroph tumours. Clinical Endocrinology 49 475-482.

Dickstein G, de Bold CR, Gaitan D, De Cherney GS, Jackson RV, Sheldon WR, Nicholson WE \& Orth DN 1996 Plasma corticotropin and cortisol responses to ovine corticotropin-releasing hormone $(\mathrm{CRH})$, arginine vasopressin (AVP), CRH plus AVP, and CRH plus metyrapone in patients with Cushing's disease. Journal of Clinical Endocrinology and Metabolism 81 2934-2941.

Engler D, Redei E \& Kola I 1999 The corticotropin-release inhibitory factor hypothesis: a review of the evidence for the existence of inhibitory as well as stimulatory hypophysiotropic regulation of adrenocorticotropin secretion and biosynthesis. Endocrine Reviews 20 460-500.

Gaillard RC, Riondel AM, Ling N \& Muller AF 1988 Corticotropin releasing factor activity of CRF-41 in normal man is potentiated by angiotensin II and vasopressin but not by desmopressin. Life Sciences 43 1935-1944.

Hedge GA, Yates MB, Marcus R \& Yates FE 1966 Site of action of vasopressin causing corticotropin release. Endocrinology 79 328-340.

Invitti C, Pecori Giraldi F, De Martin M, Cavagnini F \& The Study Group of the Italian Society of Endocrinology on the Pathophysiology of the Hypothalamic-Pituitary-Adrenal Axis 1999a Diagnosis and management of Cushing's syndrome: results of an Italian multicentre study. Journal of Clinical Endocrinology and Metabolism 84 440-448.

Invitti C, Pecori Giraldi F, Dubini A, Moroni P, Losa M, Piccoletti R \& Cavagnini F 1999 b Galanin is released by adrenocorticotropinsecreting pituitary adenomas in vivo and in vitro. Journal of Clinical Endocrinology and Metabolism 84 1351-1356.

Jessop DS 1999 Central non-glucocorticoid inhibitors of the hypothalamo-pituitary-adrenal axis. Journal of Endocrinology 160 169-180.

Kjær A, Knigge U, Bach FW \& Warberg J 1992 Histamine- and stress-induced secretion of ACTH and $\beta$-endorphin: involvement of corticotropin-releasing hormone. Neuroendocrinology 56 419-428.

Knepel W, Homolka L, Vlaskovska M \& Nutto D 1984 In vitro adrenocorticotropin/ $\beta$-endorphin-releasing activity of vasopressin analogs is related neither to pressor nor to antidiuretic activity. Endocrinology 114 1797-1804.

Legros JJ 2001 Inhibitory effect of oxytocin on corticotrope function in humans: are vasopressin and oxytocin ying-yang neurohormones? Psychoneuroendocrinology 26 649-655.
Liu JH, Muse K, Contreras P, Gibbs D, Vale WW, Rivier J \& Yen SSC 1983 Augmentation of ACTH-releasing activity of synthetic corticotropin releasing factor (CRF) by vasopressin in women. Journal of Clinical Endocrinology and Metabolism 57 1087-1089.

Lolait SJ, O'Carroll AM, Mahan LC, Felder CC, Button DC, Young WS, Mezey E \& Brownstein MJ 1995 Extrapituitary expression of the rat V1b vasopressin receptor gene. PNAS 92 6783-6787.

Malerbi DA, Mendonça BB, Liberman B, Toledo SPA, Corradini MCM, Cunha-Neto MB, Fragoso MCBV \& Wajchenberg BL 1993 The desmopressin stimulation test in the differential diagnosis of Cushing's syndrome. Clinical Endocrinology 38 463-472.

Malerbi DA, Fragoso MCBV, Vieira Filho AHG, Brenlha EML \& Mendonça BB 1996 Cortisol and adrenocorticotropin response to desmopressin in women with Cushing's disease compared with depressive illness. Journal of Clinical Endocrinology and Metabolism 81 2233-2237.

Moro M, Putignano P, Losa M, Invitti C, Maraschini C \& Cavagnini F 2000 The desmopressin test in the differential diagnosis between Cushing's disease and pseudoCushing states. Journal of Clinical Endocrinology and Metabolism 85 3569-3574.

Pecori Giraldi F \& Cavagnini F 1998 Corticotropin-releasing hormone is produced by rat corticotropes and modulates ACTH secretion in a paracrine/autocrine fashion. Journal of Clinical Investigation 101 2478-2484.

Plotsky PM, Bruhn TO \& Vale WW 1984 Central modulation of immunoreactive corticotropin-releasing factor secretion by arginine vasopressin. Endocrinology 115 1639-1641.

Putignano P, Moro M, Pecori Giraldi F, Invitti C \& Cavagnini F 1999 Stimulation by CRH and DDAVP in patients with Cushing's disease and normal subjects. Effect of basal cortisol and ACTH levels. 6th International Pituitary Congress, Long Beach, CA, USA. 81 (Abstract).

Rivier C \& Vale WW 1983 Interaction of corticotropin-releasing factor and arginine vasopressin on adrenocorticotropin secretion in vivo. Endocrinology 113 939-942.

Sakai Y, Horiba N, Tozawa F, Sakai K, Kuwayama A, Demura H \& Suda T 1997 Desmopressin stimulation test for diagnosis of ACTH-dependent Cushing's syndrome. Endocrine Journal 44 687-695.

Thibonnier M, Conarty DM, Preston JA, Wilkins PL, Berti-Mattera L \& Mattera R 1998 Molecular pharmacology of human vasopressin receptors. Advances in Experimental Medicine and Biology 449 251-276.

Tsagarakis S, Vasiliou V, Kokkoris P, Stavropoulos G \& Thalassinos N 1999 Assessment of cortisol and ACTH responses to the desmopressin test in patients with Cushing's syndrome and simple obesity. Clinical Endocrinology 51 473-477.

Received 19 February 2003

Accepted 28 February 2003 